\title{
Dolegliwości bólowe odcinka lędźwiowo-krzyżowego kręgosłupa u pracowników szczecińskich uczelni - anatomia funkcjonalna, diagnostyka, wybrane formy fizjoterapii
}

\author{
Lumbosacral ailments of the spine in workers of Szczecin Universities - functional anatomy, \\ diagnostics, and selected forms of physiotherapy
}

\author{
Wioletta Jagucka-Mętel' ${ }^{1}$ Anna Machoy-Mokrzyńska', Adam Nowicki², Ewa Sobolewska ${ }^{\circledR}$ \\ ${ }^{1}$ Pomorski Uniwersytet Medyczny w Szczecinie, Katedra i Zakład Farmakologii Doświadczalnej i Klinicznej, al. Powstańców Wlkp. 72, 70-111 Szczecin \\ Pomeranian Medical University in Szczecin, Department of Pharmacology \\ 2 Przychodnia Stomatologiczna „Mardent” w Wolinie, ul. Prosta 1, 72-510 Wolin \\ Dental Clinic "Mardent” in Wolin \\ ${ }^{3}$ Pomorski Uniwersytet Medyczny w Szczecinie, Katedra i Zakład Protetyki Stomatologicznej, al. Powstańców Wlkp. 72, 70-111 Szczecin \\ Pomeranian Medical University in Szczecin, Department of Gerodontology \\ $\triangle$ rpsobolewski@wp.pl
}

\begin{abstract}
This study aims to investigate the occurrence of lumbosacral ailments in workers of Szczecin universities who are patients of the Physiotherapy Clinic of the Independent Public University Hospital of High Schools in Szczecin. The paper focuses on the issues relating to functional anatomy, pathomechanism of pain development in the lumbosacral spine, its diagnostics, as well as the most frequently chosen forms of treatment, with particular attention to physiotherapy. These issues form an introduction to a series of reports developed on the basis of the results
\end{abstract}

obtained during a 2-year study conducted on the employees of Szczecin Universities diagnosed with changes in the lower part of the spine. This study highlights the following disorders: changes in lumbar curvature (published in the Pomeranian Journal of Life Sciences) and disorders of the sacroiliac joints, degenerative changes, intervertebral disc damage, piriformis syndrome, as well as obesity, which will be discussed in more detail in subsequent reports.

Keywords: lumbosacral dysfunction; functional anatomy; diagnostics; physiotherapy.

\section{ABSTRAKT}

W niniejszym opracowaniu zwrócono uwagę na występowanie dolegliwości bólowych odcinka lędźwiowo-krzyżowego u pracowników szczecińskich uczelni, będących pacjentami Poradni Fizjoterapii w Samodzielnym Publicznym Zakładzie Opieki Zdrowotnej Szkół Wyższych w Szczecinie. Przedstawiono zagadnienia dotyczące anatomii funkcjonalnej, patomechanizmu powstawania bólu tego odcinka kręgosłupa oraz diagnostyki i wybieranych form leczenia, ze zwróceniem szczególnej uwagi na zabiegi fizjoterapeutyczne. Zagadnienia te stanowią wprowadzenie do cyklu doniesień, które zostały opracowane na podstawie wyników uzyskanych podczas 2-letnich badań prowadzonych wśród pracowników szczecińskich szkół wyższych, u których zdiagnozowano zmiany w obrębie dolnego odcinka kręgosłupa. W przeprowadzonych badaniach zwrócono uwagę na następujące zaburzenia: zmiany krzywizny lędźwiowej (opublikowane w Pomeranian Journal of Life Sciences), zaburzenia ze strony stawów krzyżowo-biodrowych, zmiany zwyrodnieniowe, uszkodzenia krążka międzykręgowego, zespół mięśnia gruszkowatego oraz otyłość - które zostaną szczegółowo przedstawione w kolejnych doniesieniach.

Słowa kluczowe: zaburzenia odcinka lędźwiowo-krzyżowego; anatomia funkcjonalna; diagnostyka; fizjoterapia.

\section{WSTĘP}

Budowa kręgosłupa stanowi przykład nierozdzielności struktury i funkcji, dlatego do zrozumienia funkcji fizjologicznych oraz patomechanizmów powstawania zaburzeń w tym narządzie niezbędna jest nie tylko szczegółowa znajomość jego budowy anatomicznej, lecz również pełnionych przez niego funkcji. Kręgosłup jest narządem osiowym, w skład którego z punktu widzenia anatomii czynnościowej - wchodzi: kręgosłup właściwy, będący kolumną zbudowaną z kostnych kręgów połączonych krążkami międzykręgowymi i stawami międzywyrostkowymi oraz biernie ustabilizowanym systemem więzadeł i torebek stawowych; układ różnych grup mięśniowych odpowiadających za czynności statyczne i dynamiczne obsługiwanych przez nie części kostnych; układ nerwowy - w tym rdzeń i korzenie nerwowe przebiegające w kanale kręgowym oraz zlokalizowane zewnątrzkanałowo struktury układu wegetatywnego. Wymienione elementy układu nerwowego z jednej strony korzystają z ochrony części kostnych kręgosłupa, a z drugiej sterują jego czynnościami [1,2,3]. 
Kręgosłup, który jest ruchomą osią tułowia i szyi, biegnie od podstawy czaszki do dolnego końca tułowia. W jego przebiegu można wyróżnić naturalne krzywizny w postaci lordozy - skierowanej wypukłością ku przodowi, znajdującej się w odcinku szyjnym i lędźwiowym oraz kifozy - skierowanej wypukłością ku tyłowi, znajdującej się w odcinku piersiowym i krzyżowym. Wygięcia te wraz z dyskami pełnią funkcje amortyzujące, co jest szczególnie ważne w odcinku lędźwiowo-krzyżowym (L-S) - zwłaszcza podczas chodzenia, biegania czy skakania. Odcinek ten zbudowany jest z 5 kręgów lędźwiowych, z których ostatni łączy się z kością krzyżową, skierowaną wierzchołkiem ku dołowi pod kątem 120-170 . Zwiększenie bądź zmniejszenie tego kąta wpływa na lordozę lędźwiową [4]. Masywność kręgów lędźwiowych związana jest z funkcją nośną kręgosłupa. Każda jego część jest obciążona odwrotnie proporcjonalnie do wysokości, na której się znajduje. Oznacza to, że im niżej położony kręg, tym większe siły nacisku są na niego wywierane [5]. Kręgosłup jest fizjologicznie ustabilizowany poprzez więzadła kręgosłupa oraz mięśnie przykręgosłupowe. Właściwe napięcie tych dwóch struktur zapewnia jednocześnie maksymalną stabilizację i ruchomość kręgosłupa - są to najważniejsze elementy umożliwiające ruch z jednoczesnym zachowaniem całej struktury ułożenia kręgów. Ściśle związane z biomechaniką kręgosłupa są również duże grupy mięśniowe wpływające na jego kształt i funkcje, do których należą mięśnie brzucha, grzbietu oraz biodrowo-lędźwiowe [6]. W warunkach idealnych grupy mięśni idealnie spełniają swoje funkcje oraz pozwalają zachować prawidłowy wzorzec ruchowy. Może on zostać zaburzony przez niewłaściwy styl życia. Konsekwencją długotrwałego nieprawidłowego obciążenia są początkowo zmiany funkcjonalne (odwracalne). Zaburzenia te, jeśli nie będą w prawidłowy sposób leczone, mogą z czasem powodować nieodwracalne zmiany strukturalne. Zarówno w zmianach funkcjonalnych, jak i strukturalnych jednym z głównych objawów jest ból, zlokalizowany w obrębie zaburzonej struktury oraz w tkankach odległych. Charakter bólu może przybierać różne postaci. Może to być ból rozlany, nitkowaty, palący czy przeszywający. Jego nasilenie, specyfika i umiejscowienie związane są z zaburzeniem danej struktury, co powinno znaleźć potwierdzenie w badaniu podmiotowym, przedmiotowym oraz w badaniach obrazowych. Warto pamiętać, iż jakiekolwiek zaburzenie funkcjonowania któregoś z elementów anatomicznych może skutkować dolegliwościami bólowymi w obrębie odcinka lędźwiowego kręgosłupa, miednicy lub kończyn dolnych. Wyniki badań przeprowadzonych na pracownikach szczecińskich wyższych uczelni, związane z tym zagadnieniem, zostaną przedstawione w kolejnym doniesieniu.

\section{DIAGNOSTYKA}

W celu odpowiedniego zaplanowania leczenia konieczne jest ustalenie przyczyny bólu, patomechanizmu jego powstawania oraz identyfikacja struktur anatomicznych zaangażowanych w ten proces. Diagnostyka prowadzona u pacjenta z dolegliwościami bólowymi odcinka L-S składa się z kilku etapów, do których należą: badanie podmiotowe (wywiad), badanie przedmiotowe z wykorzystaniem testów funkcjonalno-czynnościowych oraz ortopedyczne i neurologiczne, a także badania obrazowe (rentgenografia - RTG, tomografia komputerowa TK, rezonans magnetyczny - MRI i inne). Obserwacja rozpoczyna się od analizy chodu, ustawienia przeciwbólowego, wzorców ruchowych, ułożenia stóp i miednicy względem innych części ciała. Wstępną obserwację rozszerzyć należy o wywiad, dzięki czemu uzyskać można zarys obrazu klinicznego. Na jego podstawie dobiera się odpowiednie testy. Do podstawowych testów należą: pomiary liniowe, pomiary obwodów, badanie ruchomości odcinka lędźwiowego i stawów krzyżowo-biodrowych, badanie długości i siły mięśniowej mięśni działających na ten rejon, badanie palpacyjne, które ma ustalić zaburzenia w strukturach mięśniowych i więzadłowych. Badając pacjenta, należy ocenić zakres ruchomości we wszystkich płaszczyznach i kierunkach, a także siłę mięśniową. Najbardziej powszechnym testem oceniającym siłę danej grupy mięśniowej jest test Lovetta. Do badań najczęściej wykorzystywanych przez fizjoterapeutów do oceny ruchomości odcinka L-S należy ocena ruchomości wg Rakowskiego oraz Sagital Frontal Transverse Rotation [7]. W celu określenia źródła bólu (korzeniowego lub pseudokorzeniowego) najczęściej wykonywane są testy Laseque'a, Bragarda, Hoovera [8, 9, 10]. Rzadziej stosowane testy z tej grupy to test Neriego, Turyna, Kerniga. Inną grupę testów, które różnicują zaburzenia w obrębie odcinka lędźwiowego kręgosłupa, stawu krzyżowo-biodrowego i stawu biodrowego, stanowią testy Patricka i Mennella [11, 12]. Jeżeli testy te wskażą na pochodzenie dolegliwości ze stawów krzyżowo-biodrowych, to należy potwierdzić obserwację testem wyprzedzania, kompresji bądź testem Derbolowskiego [13, 14]. Oceniając stawy krzyżowo-biodrowe, pod uwagę należy brać również zaburzenie w obrębie więzadeł i mięśni działających na ten staw $[15,16]$. W sytuacji gdy u pacjenta stwierdzono konflikt korzeniowo-dyskowy, zaawansowanie i rozległość zmian można ocenić, wykonując testy neurologiczne - odruch rzepkowy, skokowy, test chodzenia na palcach, test chodzenia na piętach i test korzeni S1-S2. Testy te wykazują, czy odruchy są obecne czy zniesione, wzmożone czy wygórowane, symetryczne czy asymetryczne $[17,18]$. Zniesienie odruchów stwierdza się przy przerwaniu łuku odruchowego, a więc np. w uszkodzeniu neuronu ruchowego obwodowego. Do badań neurologicznych należy także badanie czucia, które jest badaniem ważnym, choć obarczonym dużym błędem - dlatego wymagane jest kilkakrotne jego powtarzanie przy dobrej współpracy z pacjentem. Wymaga też dogłębnej znajomości unerwienia czuciowego, a także cierpliwości i dokładności. Czucie powierzchniowe dotyczy dotyku, bólu i czucia temperatury (ciepła i zimna) [14, 17].

Uzupełnieniem powyższych elementów wiedzy diagnostycznej są badania obrazowe, które służą trzem celom: rozpoznawaniu zmian strukturalnych, ocenie funkcji motorycznej (kinematyki) i ocenie funkcji statycznej (krzywizny kręgosłupa, ustawienie poszczególnych kręgów). Podstawowym badaniem obrazowym jest RTG, pozwalające wykryć zaburzenia w obrębie kręgosłupa oraz stopień ich zaawansowania. Ponadto RTG 
jest nieinwazyjne, a nakład kosztów związany z jego wykonaniem jest niewielki. Badanie to ma przede wszystkim na celu zaobserwowanie wpływu anomalii anatomicznych takich jak kręgozmyk, nieprawidłowa budowa kręgów, zaburzenia lordozy, wady postawy itp. na powstawanie zaburzeń funkcji. Pozwala również wykluczyć takie zaburzenia jak nowotwory pierwotne i przerzutowe umiejscowione w kręgosłupie lędźwiowym, osteoporozę z powikłaniami w postaci złamań patologicznych kręgów, zesztywniające zapalenie stawów kręgosłupa - co z punktu widzenia fizjoterapeuty jest niezwykle istotne dla odpowiedniego zaplanowania terapii. Standardowe badanie RTG wykonuje się w dwóch projekcjach: przednio-tylnej i bocznej. W niektórych przypadkach, w celu lepszego uwidocznienia zmian, zachodzi potrzeba wykonania projekcji dodatkowych, m.in. ujęć skośnych czy badań czynnościowych (w zgięciu i przeproście), które pozwalają na wykrycie niestabilności i kręgozmyku, a także zdjęć celowanych. Uzupełnieniem RTG może być TK lub MRI kręgosłupa, dające dokładniejszy obraz zmian patologicznych. Wybór badania należy do lekarza, który bierze pod uwagę zarówno wskazania, jak i przeciwwskazania, a także wstępną diagnozę. W szczególnych przypadkach w badaniach tych można zastosować techniki kontrastujące.

W przypadkach trudnych diagnostycznie często konieczne są konsultacje specjalistyczne: internistyczne, chirurgiczne, ginekologiczne, urologiczne - pozwalające na stwierdzenie lub wykluczenie źródła dolegliwości, które może nie być wiązane z kręgosłupem. Dobór odpowiednich badań umożliwia ustalenie prawidłowej diagnozy, dzięki której można skutecznie leczyć obserwowane zaburzenia. Do podstawowych form postępowania medycznego zaliczyć można leczenie zachowawcze (farmakologiczne i fizjoterapeutyczne). Jeśli leczenie zachowawcze nie przyniesie oczekiwanych skutków terapeutycznych, pacjent kierowany jest do lekarzy o specjalizacjach zabiegowych.

\section{POSTĘPOWANIE FIZJOTERAPEUTYCZNE}

Zagadnienie postępowania fizjoterapeutycznego związane jest z planowaniem programu terapii pacjenta, który powinien uwzględniać zabiegi w obrębie zmienionego chorobowo odcinka oraz likwidację innych patologii mających wpływ na zaburzenia występujące w danej okolicy. Holistyczne podejście biorące pod uwagę różne aspekty (strukturalne, emocjonalne) pozwala na bardziej skuteczne leczenie.

Zabiegi w obrębie łańcucha biokinematycznego kręgosłupa mają na celu zmniejszenie bądź likwidację dolegliwości bólowych, przywrócenie pełnego zakresu ruchu oraz prawidłowego wzorca ruchowego. Zabiegi fizjoterapeutyczne u pacjentów z dysfunkcjami kręgosłupa można podzielić na zabiegi ręczne, zabiegi fizykoterapeutyczne, kinezyterapię oraz autoterapię. Do zabiegów ręcznych zaliczyć można różne formy masażu leczniczego (powięziowy, głęboki, poprzeczny, segmentarny, funkcyjny), opracowanie punktów spustowych znajdujących się głównie w mięśniach posturalnych, relaksację poizometryczną, techniki energizacji mięśni, metody nerwowo-mięśniowe, mobilizację i manipulację oraz wykonywanie ślizgów stawowych w stawach krzyżowo-biodrowych i kręgosłupa, a także kinezjotaping. Pacjenci z dolegliwościami bólowymi w odcinku L-S często kierowani są przez lekarzy prowadzących na zabiegi fizykoterapeutyczne, do których zaliczana jest elektroterapia, elektromagnetoterapia, magnetoterapia, ultrasonoterapia, laseroterapia, termoterapia, światłolecznictwo, hydroterapia czy balneoterapia. Jak widać, gama zabiegów jest szeroka. Kierując pacjenta na zabiegi, należy wziąć pod uwagę jego wiek, rodzaj schorzenia, choroby współistniejące oraz wszystkie wskazania i przeciwwskazania. W zależności od czynnika sprawczego dobiera się odpowiednią formę terapii. Najlepsze dla pacjenta jest postępowanie indywidualne, gdyż każde ćwiczenie dostosowywane jest do jego potrzeb i możliwości. Nie zawsze jest to możliwe w placówkach, gdzie realizowane są zestawy ćwiczeń dla wszystkich pacjentów z bólem pochodzącym z odcinka L-S. Podejście takie w wielu przypadkach nie gwarantuje poprawy stanu pacjenta, gdyż nie jest nakierowane na źródło problemu. Jeśli u pacjenta doszło np. do zablokowania stawu krzyżowo-biodrowego, co potwierdzone zostało dodatnim testem wyprzedzania, kompresji czy Piedallu, wówczas należy uruchomić staw technikami osteopatycznymi (mobilizacje, manipulacje). Innym przykładem są pacjenci z dyskopatią, u których obraz kliniczny odpowiada poziomowi uszkodzenia. W takich przypadkach terapia powinna być ukierunkowana na odciążenie uciśniętych struktur nerwowych oraz centralizację dysku poprzez wyciągi bądź trakcję. Terapeuci coraz częściej korzystają też z metody McKenziego ze względu na jej pozytywne rezultaty.

U pacjentów, u których stwierdza się czynnik zapalny w obrębie np. nerwu kulszowego, przed przystąpieniem do terapii ręcznej wskazane jest leczenie farmakologiczne (leki przeciwzapalne) oraz zabiegi fizykoterapeutyczne, takie jak jonoforeza bądź fonoforeza z zastosowaniem środków przeciwzapalnych. Odmienną formę kinezyterapii stosuje się u pacjentów z hiperlordozą, dyslordozą czy skoliozą. Indywidualne podejście, które uwzględnia przyczynę dolegliwości oraz inne czynniki (wiek, płeć, choroby współistniejące), a także uświadomienie pacjentowi konieczności współpracy - poprawia wyniki terapeutyczne. Utrzymanie stanu poprawy zależy również od pacjenta. Prowadzona autoterapia, dostosowanie stanowiska pracy i przestrzeganie zasad ergonomii utrwalają przywrócone prawidłowe wzorce ruchowe [19].

Warto również zwrócić uwagę na metody mające na celu przywrócenie odpowiedniego balansu mięśniowego. Zarówno w dolegliwościach pochodzenia funkcjonalnego, jak i strukturalnego należy przywrócić prawidłową mechanikę ślizgu tkankowego. Przywrócenie balansu mięśniowego można osiągnąć dzięki rozluźnieniu napiętych mięśni i wzmocnieniu osłabionych mięśni. W pierwszym etapie przywrócenia równowagi mięśniowej należy opracować punkty spustowe, a następnie mięsień poddać terapii poizometrycznej. W trakcie oceny palpacyjnej należy zlokalizować obszar o największej liczbie punktów spustowych, a spośród nich zidentyfikować ten najbardziej bolesny (tzn. wyzwalający najwięcej bólu przy najmniejszej sile nacisku), który leży najbliżej linii pośrodkowej ciała. Jedną z metod wykorzystywanych w dezaktywacji 
punktów spustowych jest kompresja inhibicyjna (inaczej ischemiczna). Polega ona na wytworzeniu fali uderzeniowej w wyniku zwolnienia nacisku, czego efektem jest lokalne zwiększenie ilości tlenu. Alternatywą jest technika nacisk-rozluźnianie-nacisk, której efekt jest jeszcze bardziej wyraźny. W trakcie zabiegu opracowuje się maksymalnie pięć punktów spustowych, a u osób starszych lub wycieńczonych bólem do trzech. Oczywiste jest to, że punkty spustowe są przyczyną wielu dolegliwości, ale w niektórych przypadkach nie powinno się ich usuwać - np. u osób z dużą hipermobilnością stawów, gdyż powstawanie punktów spustowych jest formą obronną organizmu. Po wyciszeniu punktów spustowych należy „przerwać błędne koło" poprzez przywrócenie prawidłowej długości włókien mięśniowych, wprowadzając stretching lub poizometryczną relaksację mięśni [20]. Poizometryczna relaksacja mięśni to jedna z najczęściej stosowanych przez fizjoterapeutów metod zmniejszenia zwiększonego napięcia mięśniowo-powięziowego w obrębie kręgosłupa i miednicy. W metodzie tej wykorzystuje się wyzwolenie odwrotnego odruchu na rozciąganie mięśnia, poprzez wykonanie napięcia izometrycznego. Zabieg ten stosuje się wobec mięśni tonicznych, po uprzednim usunięciu punktów spustowych. Do mięśni tonicznych w obrębie kręgosłupa, miednicy i kończyn dolnych należą: mięsień prosty uda, mięsień biodrowo-lędźwiowy, mięsień czworoboczny lędźwi, mięsień prostownik grzbietu (odcinek lędźwiowy), mięśnie kulszowo-goleniowe oraz mięśnie przywodzące i odwodzące staw biodrowy. W celu utrzymania przedłużonego efektu pozabiegowego można wykorzystać aplikację plastra Kinesio Tex, a także stabilizację nerwowo-mięśniową. Ćwiczenia stabilizacji nerwowo-mięśniowej poprawiają i przywracają prawidłową synergię, syntonię i synchronię mięśni głębokich. Odbudowanie właściwej kontroli sensomotorycznej wpływa pozytywnie na stabilizację bierną [21]. Prawidłowe napięcie nerwowo-mięśniowe mięśnia wielodzielnego, przepony i miednicy przywraca odpowiednie wykonanie wzorców ruchowych kręgosłupa. Ćwiczenie mięśni długich powierzchownych nie wpływa znacząco na poprawę funkcji [22].

\section{LECZENIE FARMAKOLOGICZNE I OPERACYJNE}

Fizjoterapia niekiedy wymaga uzupełnienia leczeniem farmakologicznym. Ma ono na celu złagodzenie bólu, zmniejszenie stanu zapalnego i rozluźnienie napięcia mięśni oraz poprawę samopoczucia pacjenta. Stanowi z reguły efektywną metodę zwalczania objawów. Stosuje się najczęściej środki przeciwbólowe, niesteroidowe leki przeciwzapalne, będące elementem terapii wspomagającej. Są to środki skuteczne w zwalczaniu dolegliwości bólowych, o łagodnym i umiarkowanym natężeniu, zwłaszcza w stanach chorobowych o podłożu zapalnym [20].

W sytuacji gdy leczenie zachowawcze (fizjoterapeutyczne, farmakologiczne) nie przynosi spodziewanego efektu, pacjent może zostać zakwalifikowany do leczenia operacyjnego. Bezwzględnymi wskazaniami do wykonania zabiegu są: zaburzenia czynności zwieraczy, zespół ogona końskiego z utratą funkcji neurologicznych, przepuklina podwięzadłowa, choroba zwyrodnieniowa z zaawansowaną stenozą kanału kręgowego itp. [23, 24]. Zabiegi mające na celu odciążenie struktur nerwowych kanału kręgowego, takich jak worek oponowy wraz z zawartością (rdzeń kręgowy) oraz odciążenie korzeni nerwowo-rdzeniowych - to fenestracja, hemilaminektomia i laminektomia. Takie zabiegi operacyjne mają na celu uzyskanie efektu przeciwbólowego oraz zabezpieczenie przed komplikacjami neurologicznymi. Zdaniem wielu autorów zaledwie 1-2\% chorych wymaga zabiegów chirurgicznych [24, 25].

\section{PODSUMOWANIE}

Dobór rodzaju leczenia zależy od ustalenia czynnika patologicznego na podstawie wnikliwie przeprowadzonego wywiadu, testów klinicznych i badań obrazowych. Warto pamiętać, że jednym z najważniejszych elementów terapii jest współpraca z pacjentem. Znalezienie przyczyny dysfunkcji oraz przedstawienie pacjentowi możliwości leczenia działa motywująco i zachęca chorego do współpracy.

\section{WNIOSKI}

Prawidłowo zebrany wywiad oraz rzetelnie przeprowadzone badanie kliniczne, uzupełnione badaniami obrazowymi, pozwalają ustalić główną przyczynę dolegliwości bólowych w odcinku krzyżowo-lędźwiowym kręgosłupa. Podstawą leczenia jest eliminacja zaburzeń strukturalnych w obrębie kręgosłupa oraz tkanek otaczających. Dobór odpowiedniej, efektywnej metody terapeutycznej ma charakter indywidualny. $\mathrm{W}$ badaniach przeprowadzonych wśród pracowników szczecińskich uczelni ze zdiagnozowanymi zmianami w obrębie dolnego odcinka kręgosłupa zwrócono uwagę na następujące zaburzenia: zmiany krzywizny lędźwiowej [4] oraz zaburzenia ze strony stawów krzyżowo-biodrowych, zmiany zwyrodnieniowe, uszkodzenia krążka międzykręgowego, zespół mięśnia gruszkowatego oraz otyłość - które zostaną szczegółowo przedstawione w kolejnych doniesieniach.

Analiza zaburzeń dotyczących elementów wchodzących w skład łańcucha biokinematycznego miednicy i odcinka lędźwiowego kręgosłupa ma znaczenie w codziennej praktyce fizjoterapeuty i może pomóc w zaplanowaniu odpowiedniego leczenia, ponieważ identyfikacja struktur anatomicznych zaangażowanych w ten proces ma ścisły związek z patomechanizmem powstawania dolegliwości bólowych dolnego odcinka kręgosłupa.

\section{PIŚMIENNICTWO}

1. Stodolny J, Stodolna-Tukendorf J. Profilaktyka powstawania zaburzeń przeciążeniowych w układach ruchowo-stablizacyjnych kręgosłupa i innych elementach narządu ruchu. Kwart Ortop 2009;79(3): 299-308.

2. Panjabi MM. The stabilizing system of the spine. Part 1. Function, dysfunction, adaptation, and enhancement. J Spinal Disord 1992;5(4):383-9. 
3. Kuszewski M, Saulicz E, Myśliwiec A, Knapik A, Wolny T. Rola sztywności pasywnej mięśni kulszowo-goleniowych w procesach stabilizacji. Fizjoter Pol 2009;9(4):195-201.

4. Jagucka-Mętel W, Machoy-Mokrzyńska A, Nowicki A, Figeland A, Sobolewska E. Dolegliwości bólowe odcinka lędźwiowo-krzyżowego wynikające z zaburzenia lordozy lędźwiowej. Pomeranian J Life Sci 2017;63(1):20-3. doi: 10.21164/pomjlifesci.221.

5. Gnat R, Saulicz E, Kokosz M, Kuszewski M. Biomechaniczne aspekty nowoczesnych modeli stabilizacji miednicy. Cześć I: staw krzyżowo-biodrowy i mechanizm autoryglowania. Fizjoter Pol 2006;6(4):280-8.

6. Marciniak W, Szulc A. Wiktora Degi ortopedia i rehabilitacja. T. II. Warszawa: PZWL; 2008. p. 303-4.

7. Zembaty A. Kinezyterapia. Tom I. Kraków: Wyd. Kasper; 2002.

8. Szechliński J, Styczyński T, Świerkot J, Szmyrka-Kaczmarek M. Flupirtyna w leczeniu bólów krzyża. Reumatologia 2007;45(4):225-9.

9. Rupert MP, Lee M, Manchikanti L, Datta S, Cohen SP. Evaluation of sacroiliac joint interventions: a systematic appraisal of the literature. Pain Physician 2009;12(2):399-418.

10. Laslett M, Aprill CN, McDonald B, Young SB. Diagnosis of sacroiliac joint pain: validity of individual provocation tests and composites of tests. Man Ther 2005;10(3):207-18. doi: 10.1016/j.math.2005.01.003.

11. Poley RE, Borchers JR. Sacroiliac joint dysfunction: evaluation and treatment. Phys Sportsmed 2008;36(1):42-9. doi: 10.3810/psm.2008.12.10.

12. Robinson HS, Brox JI, Robinson R, Bjelland E, Solem S, Telje T. The reliability of selected motion - and pain provocation tests for the sacroiliac joint. Man Ther 2007;12(1):72-9. doi: 10.1016/j.math.2005.09.004.

13. Greenman PE. Principles of manual medicine. Baltimore: Williams \& Wilkins; 2003.p. 8.

14. Lewit K. Leczenie manualne zaburzeń czynności narządu ruchu. Warszawa: PZWL; 1999.

15. Arab AM, Abdollahi I, Joghataei MT, Golafshani Z, Kazemnejad A. Interand intra-examiner reliability of single and composites of selected motion palpation and pain provocation tests for sacroiliac joint. Man Ther 2009;14(2):213-21. doi: 10.1016/j.math.2008.02.004

16. van der Wurff P, Hagmeijer RH, Meyne W. Clinical tests of the sacroiliac joint. A systematic methodological review. Part 1: Reliability. Man Ther 2000;5(1):30-6. doi: 10.1054/math.1999.0228.

17. Kuijper B, Tans JT, Schimsheimer RJ, van der Kallen BF, Beelen A, Nollet F, et al. Degenerative cervical radiculopathy: diagnosis and conservative treatment. Eur J Neurol 2009;16(1):15-20. doi: 10.1111/j.14681331.2008.02365.x.

18. Fisher MA, Bajwa R, Somashekar KN. Routine electrodiagnosis and a multiparameter technique in lumbosacral radiculopathies. Acta Neurol Scand 2008;118(2):99-105. 10.1111/j.1600-0404.2007.00987.x.

19. Kurpas D, Steciwko A. Terapia pacjentów z chorobami układu mięśniowo-szkieletowego. Postępowanie w zespołach bólowych kręgosłupa i dużych stawów. Terapia 2008;9(2):90-5.

20. Jagucka-Mętel W, Brzeska P, Kijak E, Lietz-Kijak E, Machoy-Mokrzyńska A, Bułatowicz I, et al. Terapia dysfunkcji układu ruchowego narządu żucia - problem interdyscyplinarny. Przegląd metod postępowania. Mag Stomatol 2013;23(1):30-7.

21. Kuszewski M, Gnat R, Saulicz E. Stability training of the lumbo-pelvo-hip complex influence stiffness of the hamstrings: a preliminary study. Scand J Med Sci Sports 2009;19(2):260-6. doi: 10.1111/j.1600-0838.2008.00793.x.

22. Kuszewski M, Saulicz E, Knapik A, Gnat R, Ryngier P. Czy uprawianie sportu może być czynnikiem zmniejszającym ryzyko wystąpienia funkcjonalnych skróceń mięśni kulszowo-goleniowych u młodzieży? Probl Hig Epidemiol 2008;89(1):47-50.

23. Szczepański L. Bóle krzyża - częsty problem w gabinecie lekarza pierwszego kontaktu. Med Rodz 1999;7:3-9.

24. Stodolny J. Choroba przeciążeniowa kręgosłupa - epidemia naszych czasów. Kielce: ZL Natura; 1999.

25. Dziak A, Tayara S, Szczepański L. Bóle krzyża - częsty problem w gabinecie lekarza pierwszego kontaktu. Med Rodz 1999;7:3-9. 